\title{
Erratum to: Classification, shear strength, and durability of expansive clayey soil stabilized with lime and perlite
}

\author{
Umit Calik • Erol Sadoglu
}

Published online: 14 January 2014

(C) Springer Science+Business Media Dordrecht 2014

\section{Erratum to: Nat Hazards \\ DOI 10.1007/s11069-013-0950-1}

The original version of this article unfortunately contained a mistake.

Category of the article should be "Original article" instead of "Review article".

The online version of the original article can be found under doi:10.1007/s11069-013-0950-1.

\section{U. Calik}

General Directorate of Highways, 10th Reg. Dir., 61310 Akcaabat, Trabzon, Turkey

e-mail: umitcalik@outlook.com

E. Sadoglu $(\bowtie)$

Department of Civil Engineering, Karadeniz Technical University, 61080 Trabzon, Turkey

e-mail: erolsadoglu@hotmail.com 